\title{
WE CHANGED THE WAY \\ WE THINK ABOUT MOLECULES
}

Laureate of the Nobel Prize in Chemistry 2016 Jean-Pierre Sauvage talks

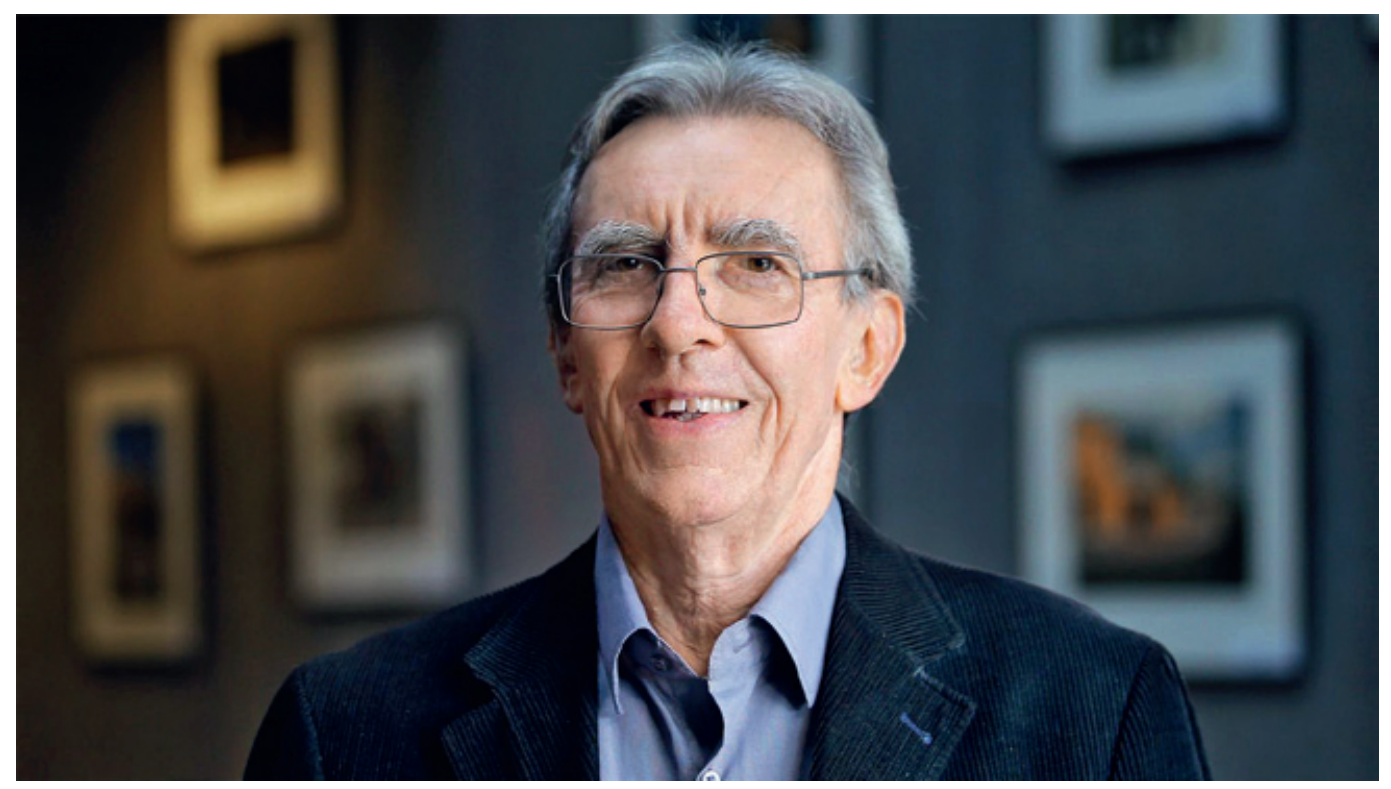

In 2016, Jean-Pierre Sauvage along with Fraser Stoddart from Northwestern University and Bernard Feringa from the University of Groningen have been awarded the Nobel Prize in Chemistry for the design and production of molecular machines. Professor Sauvage and his team managed to develop and synthesize molecular systems that produce nanoscale rotational, translational movements similar to contractions of the muscle fibers and other biological processes.

Currently, Jean-Pierre Sauvage is an honorary professor at the University of Strasbourg. He has been a visiting professor at Northwestern University (USA). On April 24, 2019 at the general meeting of the Russian Academy of Sciences he was solemnly awarded a diploma of a foreign member of the Russian Academy of Sciences.

Laureate of the Nobel Prize in Chemistry 2016 Jean-Pierre Sauvage talks about the history and prospects of development of molecular machines.

The history of molecular machines began with catenane. While planning the catenane synthesis, did you think about the possibility of creating a molecular machine, or was it just a challenging synthesis of a very fascinating structure for you?

It was a challenge: nobody had made a catenane in a satisfactory yield before. Actually, a catenane was firstly made in a fully convincing way in 1964 by Schill and Lüttringhaus as a result of 20 step synthesis'. However, in spite of its elegance, this synthesis was not reproduced by others, and the authors never published any followed-up

$1 \quad$ Angew. Chem. 1964. V. 76 (13). P. 567-568. papers. Despite the first excitement about this work people gradually lost interest in this challenging structure.

When I started my group in 1980, I was interested in water splitting. We started a grand project "Photochemical Cleavage of Water to $\mathrm{H}_{2}$ and $\mathrm{O}_{2}$ ". The most promising catalyst at that time was shown to be ruthenium tris bipyridine. But ruthenium is very expensive, and we thought it would be beneficial to replace it with cheaper copper (I) photocatalysts. We made a copper (I) complex with phenanthroline-type ligands. It was a complex containing two phenanthroline molecules with attached phenyl ring and a copper (I) atom in the center. With our collaborator, David R. McMillin (Purdue University, USA) we published several papers about the photochemical 


\section{THEY DEVELOPED}

\section{THE WORLD'S SMALLEST MACHINES}

A tiny lift, artificial muscles and minuscule motors. The Nobel Prize in Chemistry 2016 is awarded to Jean-Pierre Sauvage, Sir J. Fraser Stoddart and Bernard L. Feringa for their design and synthesis of molecular machines. They have developed molecules with controllable movements, which can perform a task when energy is added.

The development of computing demonstrates how the miniaturisation of technology can lead to a revolution. The 2016 Nobel Laureates in Chemistry have miniaturised machines and taken chemistry to a new dimension.

The first step towards a molecular machine was taken by Jean-Pierre Sauvage in 1983, when his team succeeded in linking two ring-shaped molecules together to form a chain, called a catenane. Normally, molecules are joined by strong covalent bonds in which the atoms share electrons, but in the chain they were instead linked by a freer mechanical bond. For a machine to be able to perform a task it must consist of parts that can move relative to each other. The two interlocked rings fulfilled exactly this requirement.

The second step was taken by Fraser Stoddart in 1991, when he developed a rotaxane. He threaded a molecular ring onto a thin molecular axle and demonstrated that the ring was able to move along the axle. Among his developments based on rotaxanes are a molecular lift, a molecular muscle and a molecule-based computer chip.

Bernard Feringa and his research group were the first scientists to develop a molecular motor; in 1999 they got a molecular rotor blade to spin continually in the same direction. Using molecular motors, they rotated a glass cylinder that is 10,000 times bigger than the motor and also designed a nanocar.

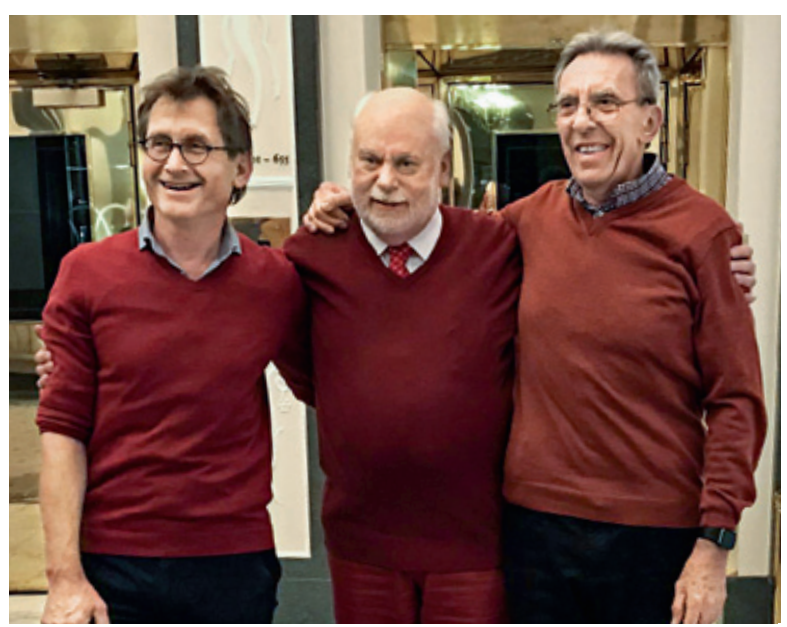

Bernard Feringa, Fraser Stoddart and Jean-Pierre Sauvage

2016's Nobel Laureates in Chemistry have taken molecular systems out of equilibrium's statemate and into energy-filled states in which their movements can be controlled. In terms of development, the molecular motor is at the same stage as the electric motor was in the 1830s, when scientists displayed various spinning cranks and wheels, unaware that they would lead to washing machines, fans and food processors. Molecular machines will most likely be used in the development of things such as new materials, sensors, drug carriers and energy storage systems.

Press release: The Nobel Prize in Chemistry 2016 nobelprize.org properties of this complex and then noticed that the complex is a perfect precursor for catenane synthesis. We suggested that we have a nice trick that can help us make a catenane easily. So, we started working on catenanes mostly because nobody had made them in a satisfactory fashion and it was a challenging task ${ }^{2}$. Our experience can show that research is not a highway or a straight line. You must be ready to jump to another field, to make a detour and to take another pathway. This was exactly what happened.

2 Tetrahedron Lett., 1983, 24,5091-5094.
A couple of years later using the same strategy of copper (I) coordination, we made a number of interlocking structures such as catenane, trefoil knot, or Solomon links. And at some stage, we obtained $70 \mathrm{mg}$ of trefoil knot-containing molecule where four phenanthroline moieties coordinated with two copper atoms were connected via $\left(\mathrm{CH}_{2} \mathrm{CH}_{2} \mathrm{O}\right)_{n}$ linkers. You can do a lot of research with $70 \mathrm{mg}$ since it is an essential amount of substance! It was only the beginning of molecular knots. We studied the properties of this fascinating molecule. For demetallation, we usually used ammonium cyanide because cyanide group forms a very insoluble compound with copper. Accidentally one time, we used potassium 

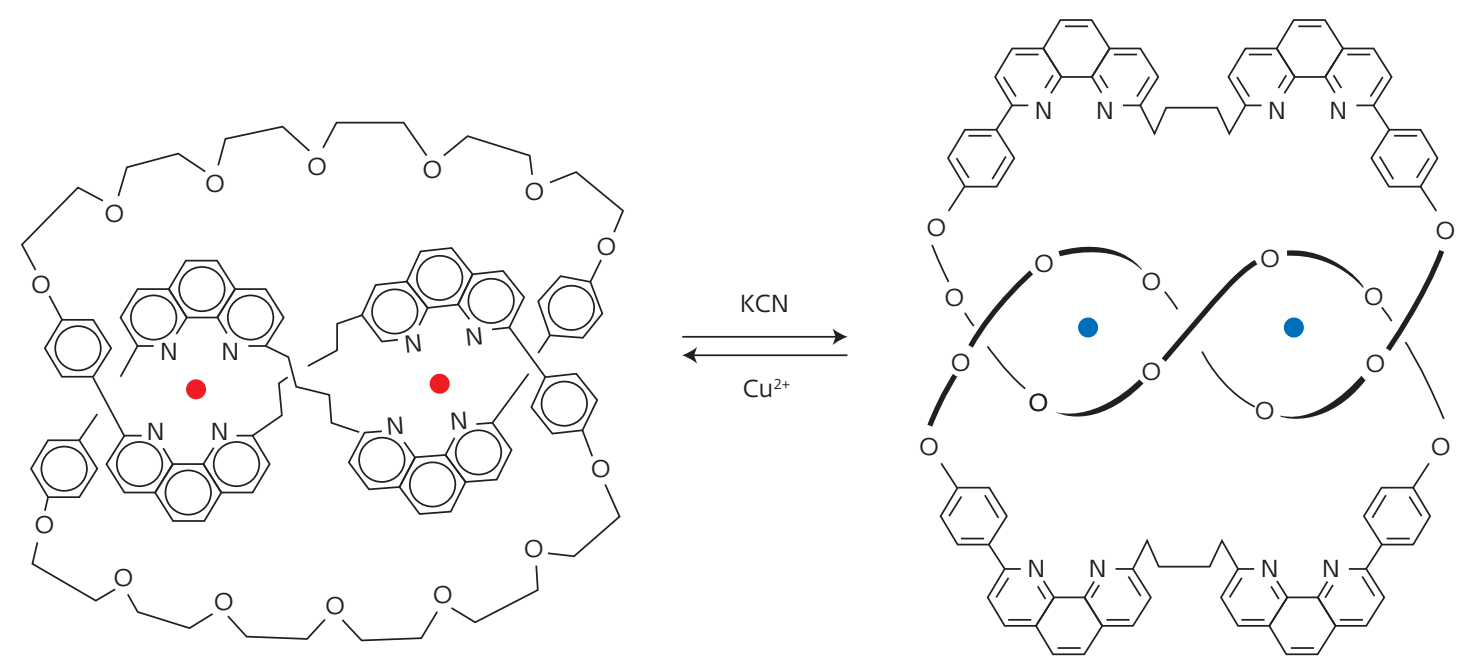

$\mathrm{Cu}^{2+}$

$\mathrm{K}^{+}$

Fig.1. Inversion of the trefoil knot

cyanide instead. As you know, potassium readily interacts with $\left(\mathrm{CH}_{2} \mathrm{CH}_{2} \mathrm{O}\right)_{n}$ moieties forming stable complexes, take crown ether as an example. So, after adding potassium cyanide, we observed that copper atom was removed, and potassium coordinated with the ether fragments forming a completely different structure: phenanthroline fragments that were in the middle of the molecule were pushed outside (Fig.1).

The inner part of the molecule could be moved to the surface and back, these two structures were completely different and possessed completely different shapes, and both reactions went quantitatively! It was not a molecular machine yet, but it was an interesting system with no precedence.

Another system made by our group for which a large amplitude motion could deliberately be triggered by an external signal was reported in 19943. A ring could be forced to rotate inside the other ring by playing with the copper (I)/copper (II) redox couple which led us to name the compound "a swinging catenane." The key feature of the transformation is the difference in preferred coordination number for the two redox states of the metal: 4 for copper (I) and 5 (or 6) for copper (II). Complete pirouetting of the ring can be easily induced electrochemically, by means of a chemical reductant

3 Journal of the American Chemical Society, 1994, 116, 9399 or oxidant, or even photochemically (Fig.2). It must be stressed that directionality of the motion was not yet controlled, which is the reason why we used the terms "pirouetting" or "swinging". Real rotary motor was firstly done in 1999 by Ben Feringa.

This work was important because it introduced an entirely new concept. For a long while molecules were considered as motionless objects that do not move or move at random. But due to the contribution of several groups in the world, the image of the molecules has changed completely. Nowadays, we can make molecules that move under a very strictly controlled fashion, such as linear motors, rotary motors, compressors, tiny muscles at a molecular level and so on, and this is a kind of revolution in chemical science.

Do catenanes and molecular machines exist in nature?

Oh yes, nature is full of catenanes. DNA forms catenanes all the time: in 1967 electron microscopy revealed catenanes made up of circular DNA isolated from the mitochondria of HeLa cells and human leukemic leucocytes. In accordance with the Cambridge database, about $2 \%$ of proteins are catenanes or knots. Bacteriophage HK97s capsid is a huge catenane system. The relatively thin bacteriophage gains additional stability by interlocking proteins in this manner, protecting the genetic information contained within 


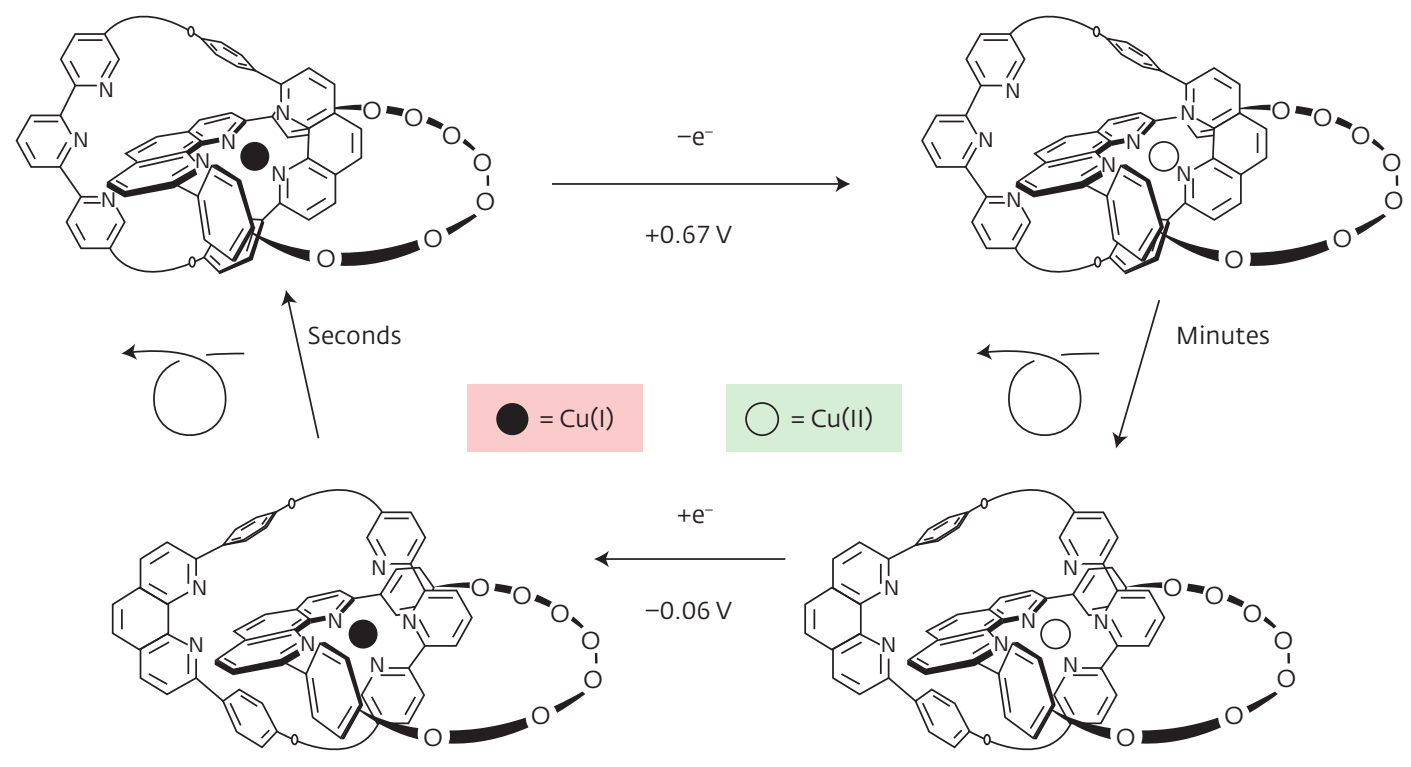

Fig.2. Pirouetting of a ring within another ring using $\mathrm{Cu}(\mathrm{II}) / \mathrm{Cu}(\mathrm{I})$ couple

the capsid, that is necessary for virus replication even in harsh environments.

In biology, controlled molecular motions are essential and omnipresent: rotary or linear motors, walkers, system undergoing contractions and extensions. Motor proteins are everywhere.

Two examples of biologically essential molecular machines are ATP-synthase which works as a rotary motor and a molecular shuttle kinesin "walking" on a microtubule.

There was a paper published in Nature in $2015^{4}$ Authors described various types of molecular machines including, among the others, compounds like combretastatin which can switch between inactive trans isomer and active cis isomer after irradiation. Don't you think that it seems quite arguable to consider this molecule as a molecular machine since no movement occurs and no work is performed? How would you define a molecular machine?

This is a complicated question. Strictly speaking, I do not believe that a molecule that undergoes cis/trans photoisomerization is a molecular machine. The people call such a molecule a switch, system that is switching between two states. However, this important field is not too far from molecular machines.

Molecular machines imply continuous motion, they should be reversible, should be able to go back and do it repeatedly. For the moment most of the molecular machines are not perfect in the sense that they have very limited ability to do work. But in the future, I believe they'll be useful at doing work and performing very precise functions.

What applications of molecular machines do you see? For example, in our magazine, we published reports about Feringa's work on incorporating molecular motors into organometallic structures and synchronizing their work, as well as molecular machines that create a hole in the cell membrane and can be used for drug delivery. What other applications are possible?

There are applications of the interlocking rings like catenanes in intelligent materials, and these materials behave in a very special way. Several companies in Japan incorporate interlocking rings into films and polymers and they are getting highly flexible materials ${ }^{5}$.

A potentially important application for the future is molecular computing, which can be used for storing and

4 Nature, 2015, 525, 18-21.

5 For example, J. APPL. POLYM. SCI. 2014, 131, 15, 40509. 
processing information. Another exciting field of research is application in medicine and, in particular, in targeting. So far, there are not too many practical applications. But potentially you can think of transporting drugs into biological fluids, drilling a hole in the bacterial cell wall (cf, the work done by J.M. Tour and co-workers, $2017^{6}$ ). Using drugs in association with molecular machines can help to carry the drug to the point where it should be delivered: to a cancer cell, a virus, a bacteria, and so on. In relatively long-term perspective, artificial muscles of various lengths, from microns to millimeters, might be needed for various applications such as humanoid robots, actuators for microfluidic science and technology, or prosthetic organs.

Nobel laureate Ben Feringa said: "We've made 50 or 60 different motors. Now I'm less interested in making another motor than actually using it." What is more interesting for you today: exploring the principles of operation and designing previously unknown molecular machines, or searching for practical applications of existing machines?

Working on the new applications and new concepts of molecular machines are both very exciting and important. But I do not have projects anymore because I closed my research group three years ago. I am kept very busy with traveling, giving lectures, meeting with people, so I don't have time to supervise Ph.D. students. Though if I still had a team working with me today, I would try to work on a new type of molecular machines that are biocompatible and can be accepted by living organisms. Nowadays, most of the machines, including Stoddart's, Feringa's, or machines from my group, being injected into the organism, are rejected by it since they are not compatible with biomaterials. In the future I expect that molecular machines injected into the organism will be able to do something: i.e. interact with enzymes or DNA.

In your biography, published on the Nobel website, you mention that you are not only familiar with Fraser Stoddart, but are also friends with him. Do you help each other in your research, discuss your plans, or does your work proceed independently?

I think it is not common that the three laureates of the Nobel Prize are very close friends. The people from the Royal Academy of Science told us that sometimes laureates don't even speak to each other, that they are very distant. This is not our case.

Fraser and I know each other since 1979, we even exchanged our kids 25 years ago. Fraser sent his daughter to

$6 \quad$ Nature. 2017, 548(7669), 567-572 my family to improve her French, and our son went to him to practice his English. It may appear surprising, but Fraser Stoddart and I never looked at each other as competitors. Even more, we both tried to avoid any overlapping with the activities of the other research team. I met with Ben Feringa in 1988 in Gottingen and we also became friends.

\section{Do you have any collaboration with Russian scientists?}

Yes, I do. I started collaborating with Yulia Gorbunova many-many years ago, even before I was awarded the Nobel Prize. She introduced me to many researchers from the Institute of Physical Chemistry and Electrochemistry named after A.N.Frumkin in Moscow: Alexander Martynov, Aslan Tsivadze, who was the head of the Institute, and others. Alexander Martynov visited my group six times, each time staying for 2 to 3 months. He visited my lab virtually every year.

We published several collaborative papers on the synthesis of complex 30-membered macrocycles containing both zinc phthalocyanine and four phenanthroline cycles? These compounds had interesting properties: being insoluble in most of organic solvents, they form a bright green solution after addition of $\mathrm{Cu}(\mathrm{I})$ ions. This occurs as a result of coordinating the phenanthroline moieties with $\mathrm{Cu}(\mathrm{I})$, due to which the molecule acquires a globular shape.

In 2017, the first Nanocar race was held in Toulouse with the support of CNRS. The second competition is planned for 2021. How do you feel about such contests? Should they be considered as a scientific entertainment, or is there some practical sense in them?

Very serious scientists took part in this race. It is not trivial; they deposit their machines on a metal surface and then demonstrate that they can move the system of nanocar ${ }^{8}$ using a scanning tunneling microscope. This concept is not completely new, but it is nice and has a great impact on the world general public, i.e. people who are not very educated in the field of science. The First Nanocar Race was followed live by more than 100.000 people on the YouTube channel. They were able to see that scientists possess brand-new techniques, deal with tiny objects, and can make the nanocars move. But for the moment I think that there is no practical application for this race. It could change in the future, of course.

Moreover, I am not sure that nanocars moving on the surface can be considered as the same type of molecular machines as those awarded by the Nobel Committee, because they are moved with a tip injecting electrons to

Eur. J. Org. Chem. 2012, 6888-6894

8 Nature Reviews Materials, 2017, 2, 6, 17040 
YULIA G. GORBUNOVA

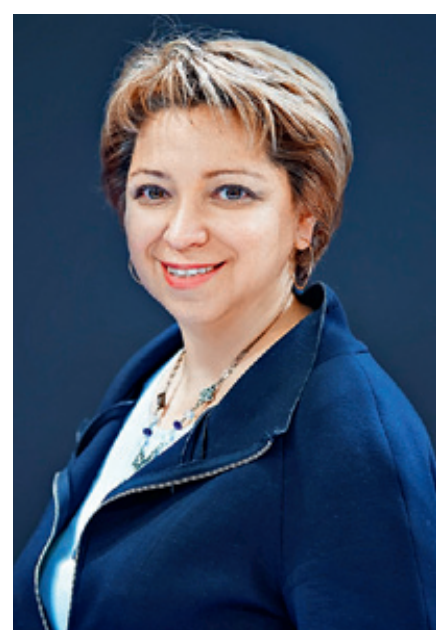

Corresponding Member of the Russian Academy of Sciences, Professor Yulia Germanovna Gorbunova is the main research associate at the Institute of Chemical Physics of the Russian Academy of Sciences, a leading Russian scientist in the field of coordination and supramolecular chemistry. Yu.G. Gorbunova proposed methods for the directed synthesis of a wide range of coordination compounds based on tetrapyrrole ligands - analogues of natural substances that ensure the life of the biological world. She developed the fundamental principles of obtaining new functional materials: thin films, polymer composites, hybrid materials based on macrocyclic compounds and supramolecular architectures, as the basis of new generation multifunctional devices.

The regularities she found made it possible to create new thin-film systems for recording, processing, and storing information, molecular switches, optical tomography, nonlinear optics, solar energy converters, magnetic materials, and photosensitizers. Julia developed conductive polymer composites containing metal phthalocyaninates for the use in optical computers with the aim of amplifying information laser beams and as non-volatile memory elements.

Yu.G. Gorbunova is thescientific secretary of the Mendeleev congresses in general and applied chemistry, a member of the organizing committee of a number of international and Russian specialized symposia, the expert of RAS, RFBR, RSF. In 2016, Julia was elected vice president of the Russian Chemical Society named after D.I. Mendeleev. In the same year, she became a member of the Council on Science and Technology of the State Duma Committee on Science and High Technology. Yulia represents Russia in the International Society of Porphyrins and Phthalocyanines SPP and the Department of Inorganic Chemistry at the European Association of Chemical and Molecular Sciences EuCheMS. She is the co-director of the Russian-French Laboratory of Macrocyclic Systems and Materials Based on Them.

Yu.G. Gorbunova is a laureate of a number of prestigious scientific prizes, including the State Prize of the Russian Federation in the field of science and technology, the Prize of RAS named after L.A. Chugaev, etc. In July 2016, by decree of the Prime Minister of the French Republic Yu.G. Gorbunova was awarded the honorary title of Knight of the Order of Academic Palms (Chevalier dans I'Ordre national des Palmes Academiques)

We asked Julia to briefly talk about the joint work of her research group with Professor J.-P. Sauvage:

"We met with Jean-Pierre Sauvage in 2005 during the signing the agreement on the creation of the European association "Supramolecular Systems in Chemistry and Biology", which included about 30 laboratories in France and about the same number in Russia. In 2007, our young and very talented employee Alexander Martynov went to the Sauvage laboratory to work on a project that we called the "Russian-French molecule".

In the course of the project, we developed an original strategy for producing molecules based on phthalocyanines - synthetic analogues of chlorophyll integrated with phenanthroline-containing macrocycles for the targeted production of new molecular machines with the topology of catenanes and rotaxanes. But the main thing is that we began to develop a new direction in our scientific group: the design of molecular machines and switches. Since then, we have obtained a number of so-called molecular switches based on phthalocyanines, the optical, magnetic and redox properties of which can be controlled by external exposure, and which simulate processes occurring in nature...

In addition to work, we are connected with Jean-Pierre Sauvage by warm friendly relations. Professor Sauvage is an amazing person. He is a strong scientific leader, a true scientific advisor. He can generate ideas and at the same time listen to colleagues and discuss any suggestions. He analyzes all current results with his employees, graduate students and postdocs in great detail. And at the same time, Jean-Pierre Sauvage is very open, lively and versatile person who loves art, music. We are very lucky: Professor Sauvage has a lot to learn in science and in life!" the surface. This tip is very close to the nanocar, and, in my opinion, in this case the machine includes the whole system: the surface, the molecule, and the tip. So, the nanocar is quite a big surface deposited machine, which is very different from the molecular machines which you irradiate with UV or visible light.

In any case, this race has a lot of impact on people who are interested in what is going on in the world of science. 


\section{NANOCAR RACE}

Nanocar Race is an international scientific competition with the aim of testing the performance of molecular machines and the scientific instruments used to control them. The race was held for the first time in Toulouse on 28 and 29 April 2017.

The molecular 'vehicles' were driven individually at the same time by different 'pilots' using scanning tunnelling microscopes (STMS). Four teams drove their nanocars on a shared gold surface at the CEMES-CNRS (French National Center for Scientific Research) race room in Toulouse, whereas the other two used remotely controlled STMS. In all cases, the metal surfaces hosting the tracks on which the nanocars raced were held in ultrahigh vacuum and at a temperature of $4 \mathrm{~K}$. Each track was $100 \mathrm{~nm}$ long and contained at least two turns. One team raced on a silver surface, with all others racing on a gold surface.

With about 100 atoms and a lateral size of $\sim 7 \mathrm{~nm}, a$ nanocar had a chassis equipped with some spacer chemical groups to hold it a few angstroms away from the supporting surface and an onboard motor-a chemical structure allowing the nanocar to move when electrons flow through it from the STM tip. The propulsion mechanism that makes a molecule move on the surface could be either inelastic (that is, related to the excitation of vibrational modes or to current-induced structural changes) or dipolar, resulting from the repulsion/ attraction between the nanocar and the bias applied with the STM tip. Making a nanocar move using the well-known pushing, pulling or sliding STM manipulation modes was forbidden by the race rules. The number of atoms per nanocar and the propulsion mechanisms were flexible.

A worldwide audience followed this first nanocar race, which was broadcasted live and attracted more than 100,000 viewers at peak times. It was a true scientific experiment offered free and live to anyone interested.

The first prize was shared by the Austrian-American team from the Universities of Rice and Graz and the Swiss team from Basel University. The American team from Ohio University turned back for no apparent reason after 20 nanometers, the German team broke 2 vehicles without being able to restart, and the Japanese team ended up giving up. The French team lost sight of its vehicle on its surface area, and was also obliged to abandon, comforting itself with the symbolic prize of the most elegant car in the competition.

The Nanocar race II, the second edition of this competition will take place in 2021 and is currently in the preparation stages with the support of the European project H2O20: MEMO (2017-2021).

Nat. Rev. Mater., 2017, 2, 17040

\begin{tabular}{|c|c|c|c|c|c|}
\hline Rice-Graz & Basel & Ohio & Dresden & Tsukuba & Toulouse \\
\hline 1st place & 1st place & 3rd place & 4th place & Fair play & Best images \\
\hline & & & & & \\
\hline \multicolumn{6}{|c|}{ Team Leader(s) } \\
\hline $\begin{array}{l}\text { Leonhard Grill } \\
\text { and James Tour }\end{array}$ & Remy Pawlack & $\begin{array}{c}\text { Saw-Wai } \\
\text { Hla and Eric } \\
\text { Masson }\end{array}$ & $\begin{array}{l}\text { Francesca } \\
\text { Moresco }\end{array}$ & Waka Nakanishi & $\begin{array}{l}\text { Gwénaël } \\
\text { Rapenne }\end{array}$ \\
\hline \multicolumn{6}{|c|}{ Surface } \\
\hline $\mathrm{Ag}(111)$ & Au(111) (shared) & $\mathrm{Au}(111)$ & Au(111) (shared) & Au(111) (shared) & $\mathrm{Au}(111)$ (shared) \\
\hline \multicolumn{6}{|c|}{ Propulsion mechanism } \\
\hline Dipolar & Inelastic & Dipolar & Inelastic & Inelastic & Inelastic \\
\hline \multicolumn{6}{|c|}{ Driving distance } \\
\hline $\begin{array}{l}150 \mathrm{~nm} \\
1.5 \text { hours }\end{array}$ & $\begin{array}{l}133 \mathrm{~nm} \\
6 \text { hours }\end{array}$ & $\begin{array}{c}43 \mathrm{~nm} \\
29 \text { hours }\end{array}$ & $\begin{array}{l}11 \mathrm{~nm} \\
\text { First hour }\end{array}$ & $\begin{array}{l}1 \mathrm{~nm} \\
\text { First hour }\end{array}$ & $\begin{array}{l}25 \text { nm by pulling } \\
\text { (not allowed) }\end{array}$ \\
\hline \multicolumn{6}{|c|}{ Incidents } \\
\hline- & - & - & $\begin{array}{l}\text { Molecule was } \\
\text { stuck on a } \\
\text { defect; molecule } \\
\text { destroyed }\end{array}$ & Motor blocked & $\begin{array}{l}\text { Molecule } \\
\text { jumped on the } \\
\text { tip }\end{array}$ \\
\hline
\end{tabular}


How important is the work-life balance for a career in science and do successful scientists have interests besides science?

I think it is case by case and depends on the people. Personally, I have other interests than chemistry. I have a completely normal family life. I go on vacation with my family every summer for at least three weeks, and also for another week during Easter and Christmas season. I do sports; my son and I use to play table tennis at a relatively good level. I do a lot of gardening and I love music. I have a full life in all respects.

I know that there is a stereotype that a scientist spends 80 hours per week in the lab, but it is only a stereotype. This is not to say that some people don't do that. I worked with Jean-Marie Lehn, the Nobel Prize winner in 1987. He devoted all his energy to science; he spent many hours in the lab. Though he plays the piano very well and practices for at least an hour every day.

So, there is no general rule, it depends on one's personality.

What do you think about the role of scientists in politics today: should they actively express their opinion or try to change the world from their laboratory?

I am sure that we have to take actions. I signed many petitions and protest letters since my Nobel award, because if you are a Nobel laureate, people listen more. In 2016, I signed an open letter together with other Nobel laureates calling for Greenpeace, the United Nations and governments around the world to stop fighting genetically modified organisms. Very recently, in France there were antiJewish actions, their activists terrified people, destroyed cemeteries, vandalized synagogues. I signed a letter of protest to support Jewish people. And many people do the same.

I think every scientist should be very active communicating with the general public. For many years scientists were living in an ivory tower completely isolated from the rest of the world. This is very bad. We are able to do our work thanks to the taxpayers' money, and the taxpayers have the right to know what we are doing with their money and why. So, we must communicate with the general public as much as we can.

It is very important for scientists to love people, to like to interact with people. Science is teamwork, and a scientist should also be able to lead a team. Leading a team means interacting with people with pleasure. If you are completely closed off, you are not able to motivate or charge your research team with positive energy.

Thank you for the interesting conversation. Professor J.-P. Sauvage was interviewed by N.Vasilevich

\section{МЕЖДУНАРОДНАЯ КОНФЕРЕНЦИЯ "УСПЕХИ СИНТЕЗА И КОМПЛЕКСООБРАЗОВАНИЯ"}

В конце апреля 2019 года в РудН состоялась 5-я Международная конференция "Успехи синтеза и комплексообразования". Конференция проводилась в рамках научных мероприятий, посвященных Международному году Периодической таблицы химических элементов под эгидой Генеральной ассамблеи ООН. Более 50 ведущих химиков из 15 стран выступили с докладами по актуальным вопросам органической, неорганической, медицинской, физической и коллоидной химии. Среди них Лауреат нобелевской премии по химии 2016 года ж.-П./Соваж, академик РАН, научный руководитель Института проблем химической физики РАН С.М.Алдошин, член-корреспондент РАН, заведующий лабораторией Института органической химии им. Н.Д.Зелинского РАН В.П.Анаников и многие другие всемирно известные исследователи в этой и смежных областях химических наук. География участников впечатляет: Бельгия, Великобритания, Германия, Израиль, Иран, Испания, Италия, Канада, Польша, Португалия, Россия, Саудовская Аравия, США, Франция, Япония.

На научном форуме обсуждался широкий ряд вопросов по проблемам современной органической химии: новые методы в органическом синтезе, синтез и свойства гетероциклических соединений, многокомпонентные и домино-реакции, стереохимия органических соединений, химия макроциклических соединений, биологически активные соединения, химия природныхпродүктов. На секции физической и коллоидной химии основное внимание было уделено фундаментальным и прикладным исследованиям в синтезе новых каталитических систем, сорбентов и их свойств, проблемам гетерогенного и гомогенного катализа, а также физико-химическим методам исследования и квантово-химическим расчетам.

Были рассмотрены современные проблемы неорганической и координационной химии: комплексообразование металлов с полифункциональными $\mathrm{N}-$-O-, S-содержащими лигандами; физико-химические исследования неорганических и координационных соединений и новых материалов; твердофазный синтез; методы рентгеновского анализа.

Обращаясь к участникам конференции, председатель оргкомитета форума профессор д.Х.н. Л.Г.Воскресенский сказал: "РудН переживает время многих изменений и встречает их во время более крупных общенациональных и глобальных перемен. Мы очень благодарны ученым, которые приехали в Москву со всех уголков мира. На протяжении всей конференции вы оставались активными и вовлеченными, тем самым помогая формировать будущее нашего университета".

$$
* * * * * ;
$$

Мы благодарим организаторов 5-й Международной конференции "Успехи синтеза и комплексообразования" и пресс-службу рудн за неоценимую помощь в организации и проведении интервью с профессором ж.-П.Соважем. Подробный репортаж по итогам конференции читайте в следующем номере нашего журнала. 